\title{
Farmer's traditional practices and management methods of stored common bean (Phaseolus vulgaris L.) insect pests in the central region of Benin Republic
}

\author{
Loko Yêyinou Laura Estelle $^{1^{*}}$, Akpo Ahouélété Joel ${ }^{1}$, Orobiyi Azize ${ }^{1}$, Toffa Joelle ${ }^{1}$ \\ and Dansi Alexandre ${ }^{2}$
}

\begin{abstract}
${ }^{1}$ Laboratory of Applied Entomology, Faculty of Sciences and Technology of Dassa (FAST-Dassa), National University of Sciences Technologies Engineering and Mathematics of Abomey (UNSTIM), BP 14 Dassa, Benin.

${ }^{2}$ Laboratory of Biotechnology, Genetic Resources and Plant and Animal Breeding (BIORAVE), FAST-Dassa, UNSTIM, BP 14 Dassa, Benin.
\end{abstract}

Received 4 September, 2018; Accepted 20 September, 2018

\begin{abstract}
Common bean (Phaseolus vulgaris L.) is a legume that contributes to food security and poverty reduction in Benin. However, there is very little information on its production constraints, varietal diversity, storage practices, storage insect management, and seed system. While these information are necessary for use in breeding programs and a better conservation of this legume. To fill these gaps, ethnobotanical surveys were conducted in 23 villages selected through central Benin using participatory rural appraisal tools and techniques. The number of beans landraces ranged from 3 to 5 per village (4.7 on averages) and from 1 to 4 per household (1.7 on average). A total of 26 common beans folk varieties, corresponding to 12 climbing bean landraces were recorded in the study area. A high rate of threat of landraces disappearance was recorded through surveyed villages. Various seeds storage tools were recorded and the seed system was essentially informal. The use of inert substances, chemical insecticides and insect repellent/insecticidal plants to control storage insects has been reported in the study area. Farmers noted a differential susceptibility of common bean landraces to storage insect pest. Our findings showed that there is an urgent need of development of integrated bean storage insect management strategies.
\end{abstract}

Key words: Constraints, common bean, insect pests, seed system, varietal diversity.

\section{INTRODUCTION}

Common bean (Phaseolus vulgaris L.) is a worldwidecultivated legume, with world production of $26,833,394$ tons in 2016 (FAO, 2016). This legume is highly appreciated in gastronomy for its texture due to their high protein and starch content (Pujolà et al., 2007). Common bean are also an excellent source of important nutrients such as iron, copper, phosphorus, magnesium, zinc, calcium, potassium and vitamins (Mojica and de Mejía, 2015; Beans are inexpensive sources of nutrients for people of lower socio-economic status in African and Latin American countries (Mojica and de Mejía, 2015). It is widely cultivated in the tropics for its green edible

${ }^{*}$ Corresponding author. Email: lokoestelle@yahoo.fr. 
leaves, green pods consumed as vegetables, dried seeds harvested at maturity (van De Luque et al., 2014).

Widely cultivated in Central and South America where it originates, common bean production in Benin is done on small plots with an annual production of 101821 tons in 2016 (FAO, 2014). In Central Benin, Phaseolus beans are grown because they improve soil quality and make a major contribution to household food security, especially for the poorest and most vulnerable (Missihoun et al., 2017). Cultivated mainly for their edible seeds, the production of common beans in Benin seems to be experiencing a regression in recent years (FAO, 2014), to the point of being threatened with extinction in certain regions of the country (Missihoun et al., 2017). In fact, the production of this legume is subject to several constraints during its cultivation and storage which lead to the disappearance of landraces and thus, to significant genetic erosion (Martínez-Castillo et al., 2008; Missihoun et al., 2017). These constraints remain very little documented in Benin, while their knowledge is an important step in the effort to develop technologies and knowledge to help improve yields and farmer income (van De Luque et al., 2014). Moreover, to develop an efficient strategy of conservation of this genetic resource, an assessment of diversity and analysis of distribution of extend of common bean landraces in Central Benin is a necessity (Loko et al., 2018).

The attack of stored common bean by insect pests is an important biotic constraint, which cause significant losses (Jones, 2016). Such losses could be quantitatively related to consumption of seed or qualitatively related to contamination from rests of insect excrements (Silva and Costa, 2016). Very little research attention has been given to storage insect pests of common bean and their traditional management practices in Benin. Consequently, farmers' knowledge of the insect species in the stored common bean and farmers' perception of the importance of insect damages in the stocks has never been assessed. Traditional practices and management used to prevent or control insect infestations have also not been documented.

It is known that, the control of insect pests in stored common bean is commonly done by chemical insecticides which, however have negative effects on health and environment (Keneni et al., 2011; Luz et al., 2017). One of the alternative approaches to use of chemical insecticides is the adoption of resistant cultivars (Luz et al., 2017). It is the best way of overcoming insect pests of common bean in an environment-friendly manner (Keneni et al., 2011). In order to develop common bean varieties resistant or tolerant to storage insect pests through varietal creation or improvement, knowledge of existing diversity remains essential (Acosta-gallegos et al., 2007; van De Luque et al., 2014). Unfortunately, apart a study of Missihoun et al. (2017) on the diversity of cultivated Phaseolus conducted in only four villages choose in 2 districts of the 6 representing the central Benin, very little information exists on the diversity of common bean and seed system prevalent in this region. Similarly, traditional storage practices of common bean remain poorly documented. On the other side, appropriate storage helps to reduce the effects of seasonality and variation in prices over the growing season and to maintain the quality of the seeds over time (Brackmann et al., 2002). It is therefore urgent to fill these gaps in order to better preserve the diversity of common beans in central Benin. The objectives of this study is to document the production constraints, varietal diversity, storage practices, storage insect management, and seed system of common bean in central region of Republic of Benin.

\section{MATERIALS AND METHODS}

\section{Study area}

Central Benin, is an area located between latitude $7^{\circ} 45^{\prime}$ and $8^{\circ} 40^{\prime}$ North and longitude $2^{\circ} 20^{\prime}$ and $2^{\circ} 35^{\prime}$ East. This region belongs entirely to the Sudano-Guinean climate transition zone with a bimodal rainfall unevenly distributed between two rainy seasons. The soils are mainly ferruginous tropical soils with concretions of crystalline basement relatively rich in minerals with very variable characteristics (Azontonde, 1991). The vegetation varies from open Savannah woodland in the south to a semi deciduous forest in the northwest. The main sociolinguistic groups are Idaatcha, Mahi, Tchabè, and related sociolinguistic groups.

\section{Study design}

A total of 23 villages were prospected in this study. These villages were selected through the six districts (Bantè, Dassa-Zoumè, Glazoué, Ouèssè, Savalou and Savè.) of central Benin the manner to ensure a good coverage of the study area and to cover all sociolinguistic groups (Figure 1). In each village, focus group discussions was made up of between 5 to 7 common bean producers of both sexes and different ages selected with the help of the village chief or farmers' organization leaders. After group discussions, farmers were interviewed individually (Orobiyi et al., 2017).

\section{Data collection}

The data was collected in the 23 selected villages through participatory research appraisal tools and techniques (individual interviews, group discussions, and direct observation) using a semistructured questionnaire (Orobiyi et al., 2017). Interviews were conducted with the help of local translators in each village to facilitate discussions with farmers (Kombo et al., 2012). In each village, focus group discussions was made up of between 5 to 7 common bean producers of both sexes and different ages selected with the help of the village chief or farmers' organization leaders. Prior to the group discussions, farmers were asked to bring in advance a seed sample of common bean they grow or know (Loko et al., 2015; Orobiyi et al., 2017). After a detailed presentation of the objectives of the research to farmers they were asked to submit the samples of different common bean landraces. Based on this, the list of common bean folk varieties grown by farmers in the village level were obtained. The distribution and extent of the 


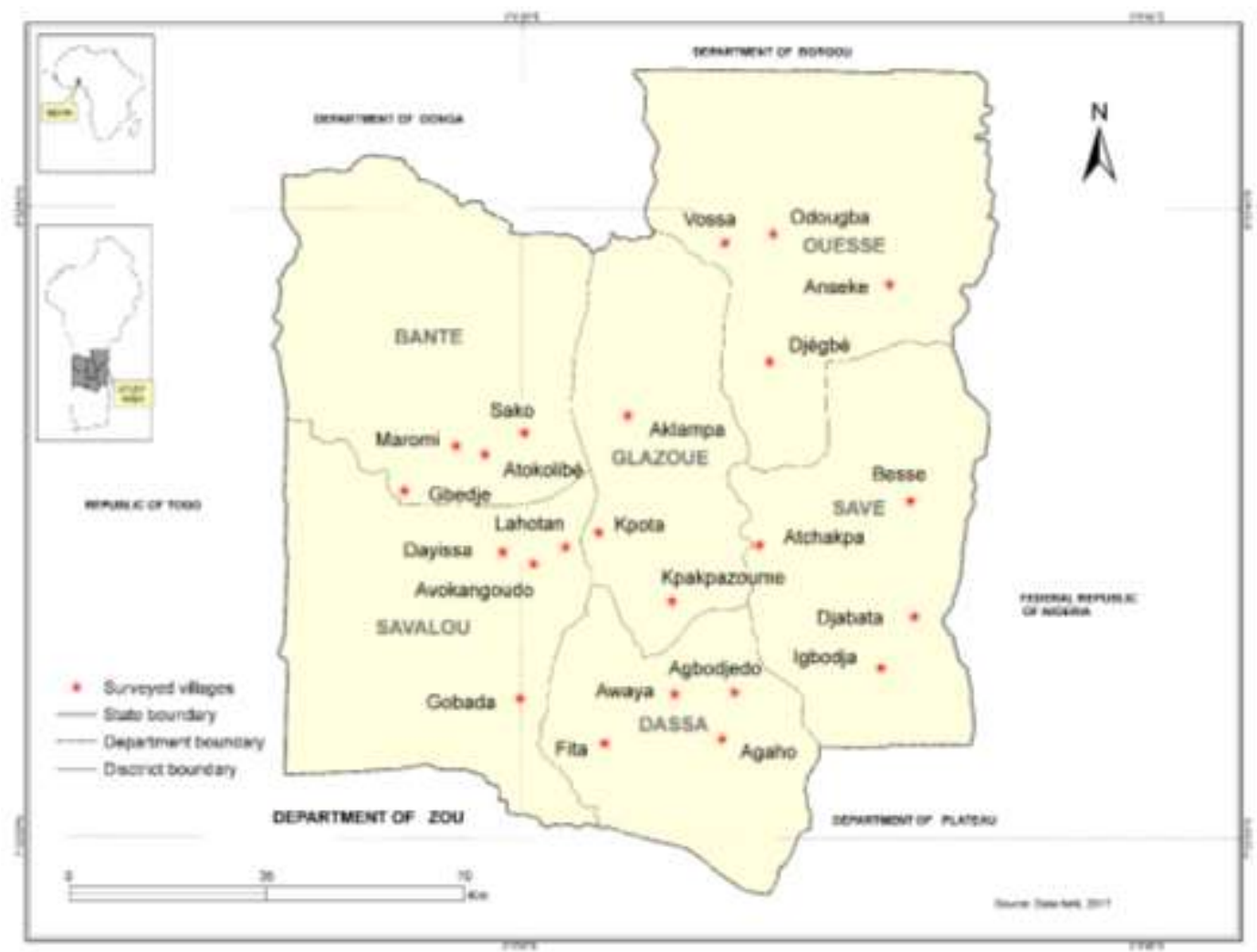

Figure 1. Map of Central Benin showing the surveyed villages.

common bean folk varieties listed were assessed using the participatory four-square analysis method according to Gbaguidi et al. (213) and Orobiyi et al. (2017). This approach allows to classify into four categories based on relative area (large or small) devoted to a folk variety and to the relative number of households (few or many) (Gbaguidi et al., 2013; Orobiyi et al., 2017). Popular folk varieties are cultivated by many households on large areas, while threatened landraces are cultivated by few households on small areas.

The data were collected during individual interviews on the base of a semi-structured questionnaire. Collected data included sociodemographic data (age, sex, household size, years of experience in common bean production, educational level), cultivated area, constraints related to common bean production, diversity maintained at the household level, the abandoned folk varieties and the reasons of their abandonment, seed system (production, supplier, conservation methods, and duration of conservation), cropping system, storage constraints, damages caused by insects, the period of the infestation, the farmers' knowledge of the storage insect species, and the traditional management practices of the infested stored beans. According to Loko et al. (2018) after interview with each farmer, common bean folk varieties were collected and classified at laboratory using visual technique following similar procedures by Mohammed et al. (2016), based on seed's morphological description characteristics (coat colour, size, coat pattern, and hilum colour).

\section{Data analysis}

The data obtained during the surveys were analysed by the descriptive statistics (mean, percentage, variance, etc.) using
Microsoft Excel 2010 software to generate figures and tables. The rate of threat of landraces disappearance (RTLD) at the level village was calculated following Kombo et al. (2012), and Orobiyi et al. (2017) according to the formula:

$\operatorname{RTLD}=[(n-k) / N] \times 100$

With $\mathrm{n}$ : number of common bean folk varieties threat of disappearance, k: number of newly introduced common bean landraces (less than a year) and $\mathrm{N}$ : the total number of common bean landrace recorded in the village. The correlation between sociodemographic characteristics of surveyed farmers and diversity of common bean landraces held at household level were calculated using the Statistical Package for Social Sciences (IBM SPSS version 23.0).

\section{RESULTS}

\section{Sociodemographic and farm characteristics of the surveyed farmers}

A total of 101 common bean producers were interviewed through the 23 prospected villages. The surveyed farmers were in majority $(77.2 \%)$ men. A great majority of surveyed farmers had no formal education (80.2\%), most farmers attained primary level of education (14.9\%), and only $4.9 \%$ of the respondents had secondary level of education. More than half of the respondents were aged between 35 and 56 with middle age, average of 51.4 
Table 1. Socio-demographic characteristics of surveyed households in the study area.

\begin{tabular}{lcccc}
\hline Demographic characteristics & Variables & Number of farmers & Percentage (\%) & Mean \pm SE \\
\hline \multirow{3}{*}{ Level of education } & No formal education & 81 & 80.2 & \\
& Primary & 15 & 14.9 & \\
& Secondary & 5 & 4.9 & \\
Age (years) & {$[35-56[$} & 66 & 65.4 & \\
& {$[56-66[$} & 28 & 27.7 & $51.4 \pm 0.9$ \\
Gender & {$[66-76]$} & 7 & 6.9 & \\
& Male & 78 & 77.2 & \\
\multirow{2}{*}{ Experience (years) } & Female & 23 & 22.8 & \\
& & & & \\
& {$[1-11[$} & 34 & 53.7 & $14.5 \pm 0.6$ \\
Land size & {$[11-22[$} & 60 & 6.4 & \\
\hline
\end{tabular}

${ }^{*} \mathrm{n}=$ number of interviewed household heads; $\mathrm{SE}=$ standard error of the mean.

years (Table 1). The experience of surveyed farmers in common bean production ranges from 01 to 32 years with an average farming experience of 14.5 years. The land size of common bean averaged 0.08 ha with a minimum of 0.02 ha and a maximum of 0.8 ha. The majority of farmers $(89.1 \%)$ grow beans on small plots of size between 0.02 and 0.1 ha (Table 1). The great majority of farmers $(72.28 \%)$ grow common beans in monoculture. While only $27.72 \%$ of surveyed farmers grow common bean intercropping with maize at the maturity stage $(70.37 \%)$ or cassava $(29.63 \%)$. Several ethnic groups were represented: Mahi $(31.7 \%)$, Idaatcha $(21.8 \%)$, Fon (17.8\%), Nago (10.9\%), Ifê $(7.9 \%)$, Tchabè (5.9\%), and Adja (4\%).

\section{Constraint of common bean production}

In central Benin, farmers face several constraints related to common bean production. In total, 12 constraints were identified and prioritized in the study area (Figure 2). Among them, availability of staking materials (29.7\%), lack of market $(18.9 \%)$, lack of seeds $(15 \%)$, drought $(12.9 \%)$, soil poverty $(9.1 \%)$, and harvest difficulties (7.3\%) were the most important (Figure 2).

\section{Common bean landraces richness}

A total of 26 vernacular names of common bean were recorded in the study area, which correspond subject to synonymies at 12 landraces, classified by farmers mainly by the colour of their seed coat (Table 2). Farmers notified that, all landraces grown in their fields are climbing beans. At the household level, the number of common bean landraces held by farmers ranges from 1 to 5 . Most of surveyed farmers (43.5\%) cultivated only one common bean landrace, while $48.5 \%$ cultivated 2 landraces and $5.9 \%$ cultivate 3 to 4 landraces. The highest number of common bean landraces (5) per household was reported in Atchakpa and Igbodja villages maintained by only $2 \%$ of surveyed farmers. There was significant positive correlation $(r=0.277, \quad p=0.005)$ between the level of education and the number of common bean landraces held by household. While, there was no significant correlation between the number of landraces held by household and age of farmers ( $r=-$ $0.079, p=0.435)$, sex of respondent $(r=0.089, p=0.376)$, farming experience $(r=-0.050, p=0.618)$ and land size $(r=-$ $0.157, \mathrm{p}=0.116)$.

\section{Distribution and extent of common bean landraces}

The number of common bean landraces per village ranged from 3 to 7 with an average of 4.7 per village. The Sako, Djegbe and Gobada villages recorded the smallest number (3) of landraces, while the Doyissa, Enseke villages showed the greatest varietal diversity (Table 3 ). Within the 12 common bean landraces collected, subject to synonymy, the landrace with large flat seed and white seed coat colour called Akpakoun wéwé and those with small seed with brown seed coat colour and dark hilum colour called Séssé were registered as popular landraces 


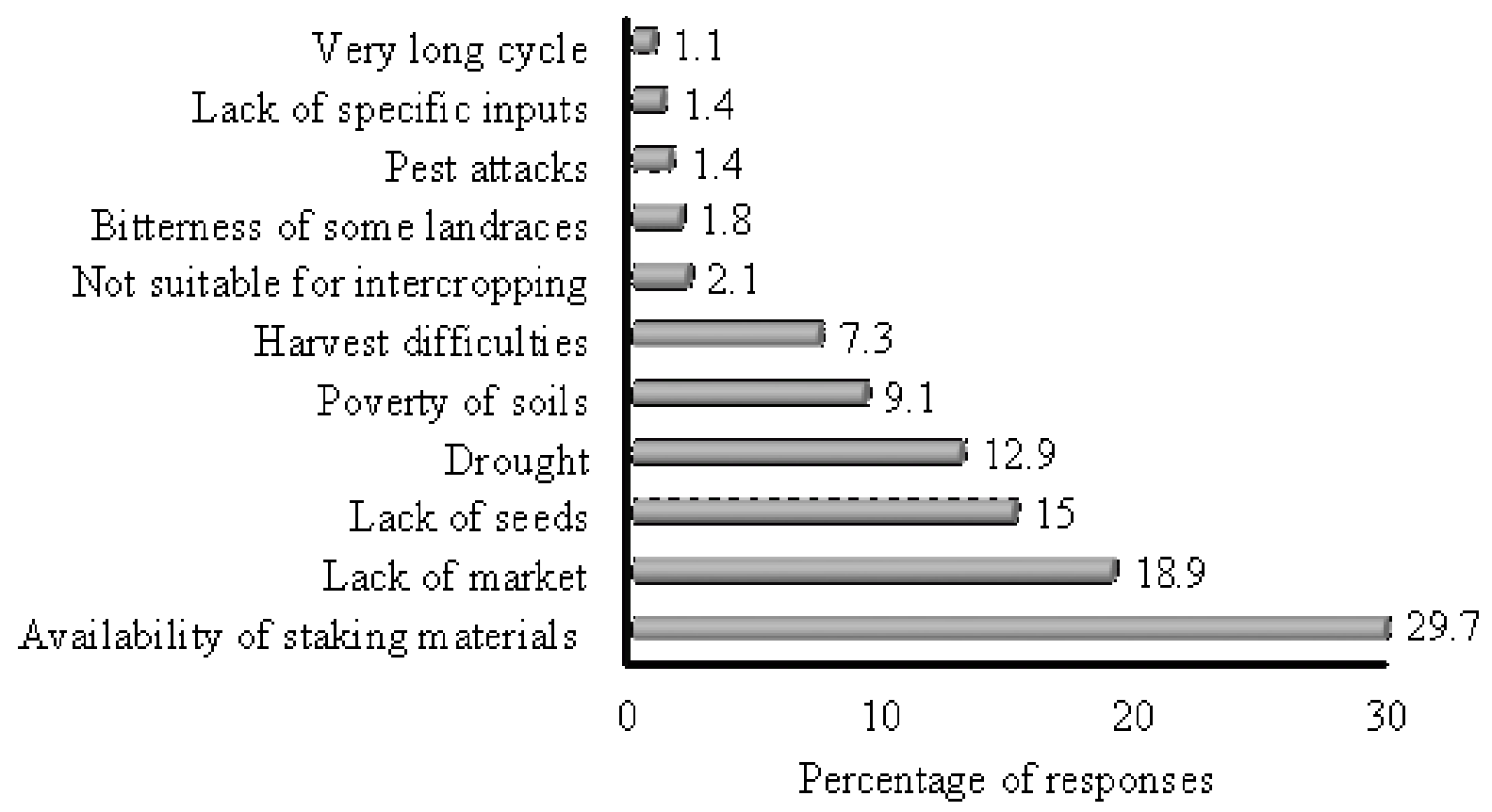

Figure 2. Constraints related to common bean production in central Benin.

and found in several villages (Table 2). It was noted that no common bean landraces were newly introduced at the village level. The majority of common bean landraces found in the study area were threatened of disappearance. The rate of threat of landraces disappearance varied from 25 to $100 \%$ with an average of $62.7 \%$. The villages of Enssèkè, Lahotan and Awaya recorded the highest rate of varietal diversity in disappearance. Across the study area the majority of respondents (54.5\%) listed landraces that they abandoned for various reasons. Akpakoun wiwi $(34.6 \%)$, Séssé $(29.1 \%)$, Akpakoun vovo $(21.8 \%)$ and Akpakoun wéwé (14.5\%) were totally abandoned by some farmers in the study area. In total, 11 reasons justifying the loss of common bean varietal diversity in the study area were listed by surveyed farmers. These reasons can be grouped into four categories, agronomic (35.5\% of responses), culinary $(22.6 \%$ of responses), commercial $(25.8 \%$ of responses) and religious $(16.1 \%$ of responses). The main reasons that threaten bean diversity in the study area were: slumps of sales $(25.8 \%$ of responses), bitter taste of some common bean landraces (22.6\% of responses), religious prohibitions $(16.1 \%)$, lack of tutors $(8.1 \%$ of responses), and seed colour (6.5\% of responses) (Figure 3 ).

\section{Seed system}

Most of surveyed farmers (51.8\%) saved seeds obtained from the previous season for the next season. Some farmers $(44.6 \%)$ use seeds bought at the market, while few farmers obtain seeds through donations $(1.8 \%$ of farmers) or inheritance from parents (1.8\% of farmers). In the context of seed conservation, only a few surveyed farmers $(20.8 \%)$ do not make any selection of bean seeds before storage. On the other hand, the vast majority of farmers $(79.2 \%)$ select the seeds before their conservation for several reasons, the most important of which was to obtain quality seeds $(40.2 \%$ of responses), vigorous plants after sowing ( $26.4 \%$ of responses), a high germination rate (19.5\% of responses), and a good yield (8.1\% of response). Very few producers select seeds for healthy plants $(4.6 \%)$ or to prevent the risk of insect attack (1.2\%). The selection of the seeds that will constitute the seeds of the next season generally relates to several criteria (Figure 4). Farmers mainly orient their choice on unperforated seeds $(63.6 \%)$ or large pods (26.5\%) and pod length (3.3\%).

Several storage methods were chosen by the surveyed farmers for seeds conservation such as polyethylene bags $(41.2 \%$ of responses), cans $(29.8 \%$ of responses), gourds $(13.2 \%$ of responses), plastic bottles $(12.3 \%$ of responses), jars (2.6\% of reponses) and clay pots $(0.9 \%$ of responses). Storage methods of common been seeds identified in the study area were living houses (90.4\%), granaries $(8.7 \%$ of farmers) and hanging on the roof kitchen $(0.9 \%)$. Most of surveyed famers $(75.9 \%)$ perceived that bean seeds can be kept for 5 to 7 months and only a few farmers (3.6\%) note a conservation of about one year (Figure 5a). Few surveyed farmers (1.8\%) reveal that stored common bean seeds were attacked by insects from the first days of storage. However, the majority of them report that heavy insect infestations occur during the second (35.9\% of responses) and third 
Table 2. Local names, characteristics, distribution and extent, and picture of common bean landraces cultivated in the study area.

\begin{tabular}{|c|c|c|c|c|}
\hline Vernacular names & Ethnic groups & Characteristics & Distribution and extent (villages) & Pictures \\
\hline $\begin{array}{l}\text { Akpakoun wéwé } \\
\text { Kpalakoun } \\
\text { founfoun } \\
\text { Kpakpalaegui }\end{array}$ & $\begin{array}{l}\text { Fon, Mahi } \\
\text { Idaatcha, Tchabe } \\
\text { Adja, Nago }\end{array}$ & Large flat seed with white seed coat colour & $\begin{array}{l}+ \text { + (Agao, Enssekè, Vossa, Avokangoudo, Djegbé, } \\
\text { Odougba, Aklamkpa, Doyissa) } \\
+ \text { - (Kpota, Fita, Atchakpa, Kpakpa-zoumè, Agbodjedo) } \\
\text { - - (Gobada, Igbodja, Béssé, Djabata, Malomie, Lahotan) }\end{array}$ & \\
\hline $\begin{array}{l}\text { Akpakoun vovo } \\
\text { Kpalakoun kpikpa } \\
\text { Kpankoui rouge } \\
\text { Kpokpodo }\end{array}$ & $\begin{array}{l}\text { Fon, Mahi } \\
\text { Idaatcha, Nago } \\
\text { Adja } \\
\text { Tchabè }\end{array}$ & $\begin{array}{l}\text { Small smooth and shiny seed with red seed } \\
\text { coat colour }\end{array}$ & $\begin{array}{l}\text { + - (Agao, Gobada, Awaya) } \\
\text { - - (Kpota, Fita, Enssekè, Atchakpa, Igbodja, Besse, } \\
\text { Djabata, Sako, Atokolibe, Kpakpa-zoumé, Odougba, } \\
\text { Agbodjedo, Avokangoudo, Aklamkpa, Doyissa) }\end{array}$ & \\
\hline Séssé & $\begin{array}{l}\text { Fon, Mahi, } \\
\text { Idaatcha, } \\
\text { Tchabè, Nago, Ifé }\end{array}$ & $\begin{array}{l}\text { Small seed with brown seed coat colour and } \\
\text { dark hilum colour }\end{array}$ & $\begin{array}{l}++(\text { Besse, Atokolibe) } \\
+ \text { - (Atchakpa, Igbodja, Gbedje) } \\
\text { - + (Agao) } \\
\text { - - (Kpota, Fita, Gobada, Enssekè, Djabata, Sako, Malomie, } \\
\text { Kpakpa-zoumé, Agbodjedo, Lahotan, Avokangoudo) }\end{array}$ & \\
\hline Kpalagui & Ifè & & & \\
\hline $\begin{array}{l}\text { Akpalakoun } \\
\text { founfoun }\end{array}$ & Idaatcha, Tchabè & Small flat seed with white seed coat colour & $\begin{array}{l}\text { + - (Atokolibé) } \\
\text { - - (Kpota, Agao, Atchakpa, Sako, Djegbe, Odougba, } \\
\text { Aklamkpa, Doyissa) }\end{array}$ & \\
\hline $\begin{array}{l}\text { Akpakoun } \\
\text { sonhouékan } \\
\text { Alawoaho }\end{array}$ & $\begin{array}{l}\text { Fon } \\
\text { Tchabè }\end{array}$ & $\begin{array}{l}\text { Small seed with marginal seed coat speckled } \\
\text { of red and a red colour around hilum }\end{array}$ & $\begin{array}{l}+ \text { - (Gbedje, Malomi) } \\
-+(\text { Gobada }) \\
\text { - - (Fita, Ensseke, Atchakpa, Igbodja, Besse, Atokolibé, } \\
\text { Djegbe, Doyissa) }\end{array}$ & \\
\hline $\begin{array}{l}\text { Akpakoun } \\
\text { Kpalakoun }\end{array}$ & $\begin{array}{l}\text { Fon, Mahi } \\
\text { Idaatcha, Tchabè }\end{array}$ & $\begin{array}{l}\text { Small seed with red broad striped seed coat } \\
\text { pattern and red colour around hilum }\end{array}$ & - - (Awaya, Enssekè, Lahotan) & \\
\hline Akpakoun djihikoun & Fon, Mahi & & & \\
\hline Ewaarigui & Nago & $\begin{array}{l}\text { Small seed with brown seed coat and red } \\
\text { colour around the hilum }\end{array}$ & - - (Ensseke, Sako, Vossa, Lahotan, Doyissa) & \\
\hline
\end{tabular}


Table 2. Contd.

\begin{tabular}{|c|c|c|c|c|}
\hline Akpakoun wiwi & Fon & $\begin{array}{l}\text { Small seed with black broad striped seed coat pattern and black colour } \\
\text { around hilum }\end{array}$ & - - (Fita, Awaya, Igbodja, Kpakpa-zoumé, Odougba) & $\cos ^{2} \mathrm{x}^{2}$ \\
\hline $\begin{array}{l}\text { Akpakoun wiwi } \\
\text { Kpankoui }\end{array}$ & $\begin{array}{l}\text { Fon } \\
\text { Mahi }\end{array}$ & Large seed with black seed coat & $\begin{array}{l}\text { - - (Kpota, Fita, Agao, Awaya, Djabata, Vossa, } \\
\text { Kpakpa-zoumé, Aklamkpa) } \\
\text { +-(Ensseke, Agbodjedo, }\end{array}$ & \\
\hline $\begin{array}{l}\text { Mitohikoun } \\
\text { Djihikoun }\end{array}$ & $\begin{array}{l}\text { Fon } \\
\text { Mahi }\end{array}$ & Small shiny round brown seeds with black colour around hilum & - - (Djegbé, Aklamkpa) & \\
\hline Akpakouin kpikpa & $\begin{array}{l}\text { Tchabé } \\
\text { Idaatcha }\end{array}$ & Large flat seed with red seed coat & $\begin{array}{l}\text { - - (Kpota, Atchakpa, } \quad \text { Kpakpa-zoumè, } \\
\text { Agbodjedo, Aklamkpa, Doyissa) }\end{array}$ & \\
\hline Mitohikoun & Mahi & & & \\
\hline $\begin{array}{l}\text { Akpakoun wéwé } \\
\text { gbagba }\end{array}$ & Fon & Small white smooth seed with black colour around hilum & - - (Agao, Awaya, Igbodja, Vossa, Djegbe) & \\
\hline
\end{tabular}

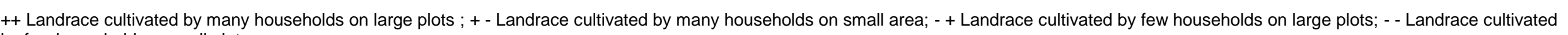
by few household on small plots.

\section{(50\% of responses) months of storage (Figure $5 b)$.}

\section{Constraints of common bean post-harvest conservation}

Most of surveyed farmers (68.3\%) report constraints related to the storage of bean seeds, mainly insect attacks by seeds $(78.3 \%)$ and grain discoloration due to fungi $(21.7 \%)$. Only a few farmers $(35.2 \%)$ were able to identify a single storage insect related to stored common bean. The bean weevil Acanthoscelides obtectus (Say) (Coleoptera: Bruchidae) known locally as Kokoroêwa (Nago), Kpokpoui (Adja) Phophoro (Idaatcha) and Wanvou (Fon and Mahi) was the only insect pests reported by farmers. Some farmers $(9 \%)$ notified that insect pests don't cause damage in stored common beans. However, most of surveyed farmers estimate losses due to storage insects at around $25 \%$ of stocks $(68.5 \%$ of respondents) and only a few farmers estimate losses at around 50\% (16.9\% of respondents), and $75 \%$ of stocks (5.6\% of respondents). Surveyed farmers listed 8 factors favouring the attack of stored common bean seeds by insects. Among them, seeds with high moisture $(40.8 \%)$, the lack of adequate storage tools (20.8\%) and the high temperature in the storage structure that allow rapid multiplication of some insects (16\%) were the most important factors (Figure 6). These heavily infested seeds were discarded by the majority of farmers (85.8\%). However, some farmers $(8.1 \%)$ after drying over several days used these seeds for consumption. Few surveyed 
Table 3. Diversity, distribution, extent and rate of threat of common bean landraces disappearance at the level of villages.

\begin{tabular}{lcccccccc}
\hline \multirow{2}{*}{ Villages } & \multirow{2}{*}{ TNL } & \multicolumn{9}{c}{ Distribution and extent } & \multirow{2}{*}{ NNIL } & \multirow{2}{*}{ NLD } & \multirow{2}{*}{ RTLD (\%) } \\
\cline { 3 - 6 } Sako & 3 & 1 & 0 & 0 & 2 & 0 & 2 & 66.7 \\
Gbedje & 4 & 2 & 1 & 0 & 1 & 0 & 1 & 25 \\
Atokolibe & 4 & 1 & 1 & 0 & 2 & 0 & 2 & 50 \\
Malomie & 4 & 1 & 1 & 1 & 1 & 0 & 1 & 25 \\
Vossa & 4 & 1 & 0 & 2 & 1 & 0 & 1 & 25 \\
Djegbe & 3 & 1 & 0 & 0 & 2 & 0 & 2 & 66.7 \\
Ensseke & 7 & 1 & 0 & 0 & 6 & 0 & 6 & 85.7 \\
Odougba & 4 & 0 & 1 & 0 & 3 & 0 & 3 & 75 \\
Atchakpa & 6 & 0 & 2 & 0 & 4 & 0 & 4 & 66.7 \\
Igbodja & 6 & 0 & 1 & 0 & 5 & 0 & 5 & 83.3 \\
Besse & 4 & 1 & 0 & 0 & 3 & 0 & 3 & 75 \\
Djabata & 4 & 0 & 1 & 0 & 3 & 0 & 3 & 75 \\
Aklamkpa & 5 & 0 & 1 & 0 & 4 & 0 & 4 & 80 \\
Kpota & 5 & 0 & 1 & 0 & 4 & 0 & 4 & 80 \\
Kpakpa-zoume & 6 & 0 & 1 & 0 & 5 & 0 & 5 & 83.3 \\
Fita & 5 & 1 & 0 & 0 & 4 & 0 & 4 & 80 \\
Agbodjedo & 5 & 0 & 1 & 0 & 4 & 0 & 4 & 80 \\
Agao & 6 & 0 & 1 & 0 & 4 & 0 & 4 & 66.7 \\
Awaya & 5 & 0 & 0 & 0 & 5 & 0 & 5 & 100 \\
Gobada & 3 & 0 & 1 & 0 & 2 & 0 & 2 & 66.7 \\
Lahotan & 5 & 0 & 0 & 0 & 5 & 0 & 5 & 100 \\
Doyissa & 7 & 0 & 1 & 1 & 5 & 0 & 5 & 71.4 \\
Avokangoudo & 3 & 0 & 2 & 0 & 1 & 0 & 1 & 33.3 \\
\hline
\end{tabular}

TNL: Total number of landraces; $\mathrm{H}+\mathrm{A}+$ : Landraces cultivated by many households on large plots; $\mathrm{H}+\mathrm{A}-:$ : Landraces cultivated by many households on small plots; H-A+: Landraces cultivated by few households on large plots; H-A-: Landraces cultivated by few household on small plots; NNIL: number of newly introduced landraces; NLD: number of landraces threat of disappearance; RTLD: Rate of threat of landraces disappearance



Figure 3. Reasons of common bean landraces loss in the study area. 




Figure 4. Famers' selection criteria of common bean seeds in the study area.

(a)



(b)



Figure 5. Farmer perception of (a) the duration of post-harvest conservation of common bean seeds; (b) the period of infestation of stored common bean by insects.

farmers $(6.1 \%)$ used infested seeds for animals feed.

\section{Insect pest management methods used by farmers}

Across the study area, most of surveyed farmers (58.4\%) take precautions to prevent insect pests attack in stored common bean. The majority of them use medicinal plants with insecticidal or insect repellent effect $(88.7 \%$ of responses). The study found that six plant species that were used to prevent infestation of bean seeds. Of these species, four (Cinchona officinalis L., Khaya senegalensis (Desr.) A.Juss., Xylopia aethiopica (Dunal) A.Rich., and Capsicum frutescens L.) were reported as insect 
Table 4. List of repellent and/or insecticidal plants used to protect stored common bean seeds against insect pests and their utilisation.

\begin{tabular}{|c|c|c|c|c|}
\hline Plants & $\begin{array}{l}\text { Percentage } \\
\text { of farmers }\end{array}$ & Part used & Method of utilisation & Role \\
\hline Azadirachta indica & 30.8 & Leaves and seeds & $\begin{array}{l}\text { Leaves or seeds dried then ground and } \\
\text { mixed with seeds beans }\end{array}$ & $\begin{array}{l}\text { Insecticide and insect } \\
\text { repellent }\end{array}$ \\
\hline Combretum micranthum & 20.4 & Leaves & $\begin{array}{l}\text { Dried and ground leaves then mix with } \\
\text { seeds beans }\end{array}$ & Insect repellent \\
\hline Khaya senegalensis & 15.4 & Leaves & $\begin{array}{l}\text { Dried and ground leaves then mix with } \\
\text { seeds beans }\end{array}$ & Insect repellent \\
\hline Xylopia aethiopica & 15.4 & Fruits & $\begin{array}{l}\text { Fruits dried, crushed and mixed with } \\
\text { seeds beans }\end{array}$ & Insect repellent \\
\hline Capsicum frutescens & 10.3 & Leaves and fruits & $\begin{array}{l}\text { Leaves and dried fruits, then ground and } \\
\text { mixed with seeds beans }\end{array}$ & Insect repellent \\
\hline Ocimum gratissimum & 7.7 & Leaves & $\begin{array}{l}\text { Grind dried leaves in preserved seeds } \\
\text { beans }\end{array}$ & $\begin{array}{l}\text { Insecticide and insect } \\
\text { repellent }\end{array}$ \\
\hline
\end{tabular}

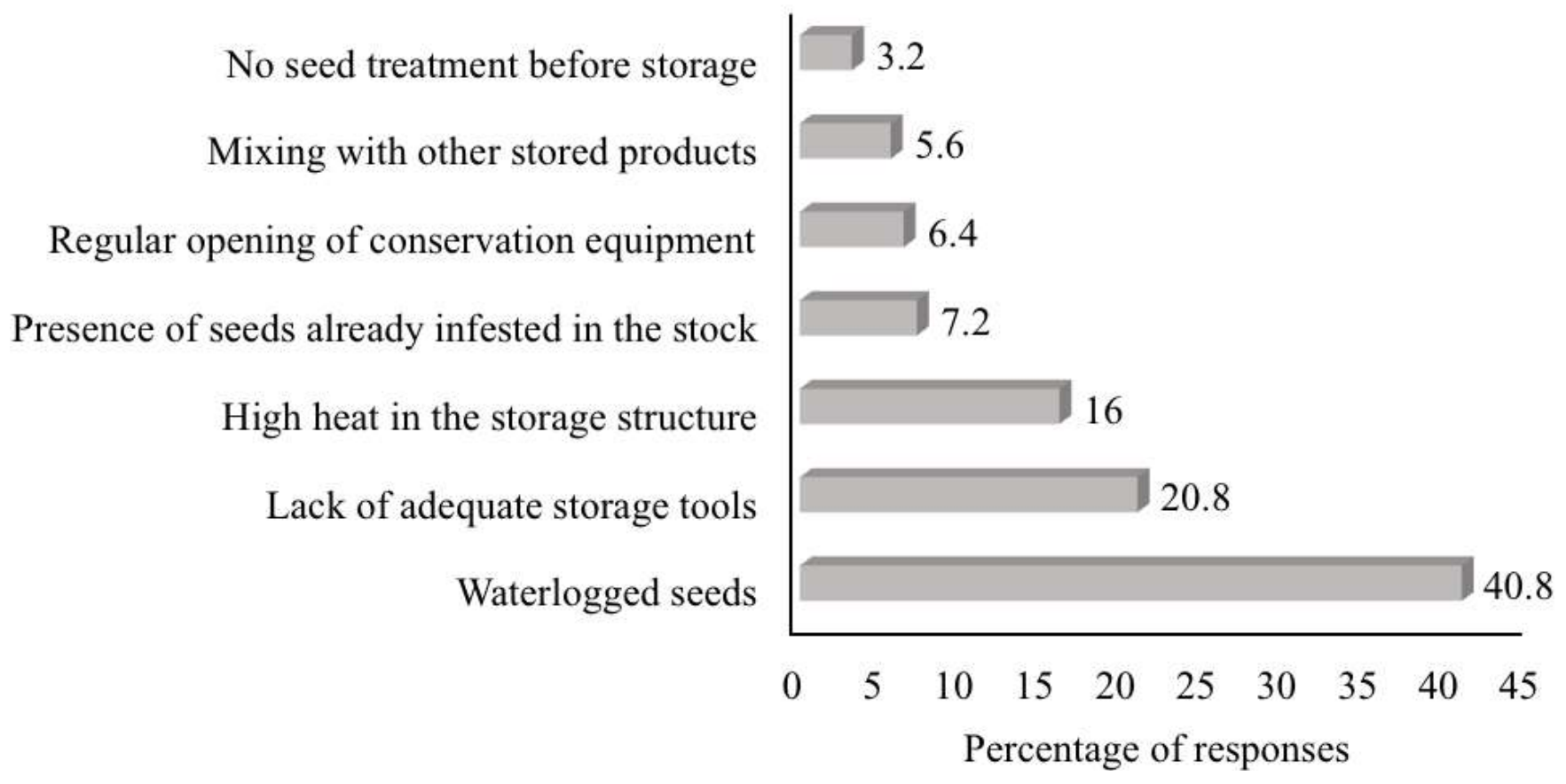

Figure 6. Farmers' perceptions of factors favouring attacks of stored common bean seed by insects.

repellents, while the other (Azadirachta indica A. Juss., and Ocimum gratissimum L.) were considered both insect repellents and insecticides (Table 4$)$. Neem ( $A$. indica) was the most used by farmers $(30.8 \%$ of respondents) and 0 . gratissimum was the less used by farmers $(7.7 \%$ of respondents). The parts of the plant (leaves or fruit) used and methods of application (ground or crushed) are summarized in Table 4 . Some farmers $(2.3 \%$ of responses) used well-sorted runoff sand dried in the sun for storage at half the volume of seed to be stored for common bean preservation. Other farmers used ash ( $4.5 \%$ of responses) which was well leached and dried to prevent discoloration and the loss of seed germination potential. Other farmers (4.5\%) used chemicals for stored common bean protection such as Sofagrin and insecticides used for cotton protection such as Andosulfan, and Lamda super 2.5 EC.

\section{Farmer perception of the resistance of common bean landraces to storage insects}

All surveyed farmers in the study area pointed out that unlike other legume seeds such as cowpea, soybean or 
Kersting's groundnut, common bean landraces were resistant to storage insects. However, they noted that four common bean landraces were very resistant to storage insect attacks. These are the Séssé $(57.8 \%$ of farmers), Akpakoun vovo (33.3\% of farmers), Akpakoun wiwi $(6.7 \%$ of farmers), and Mitoyikoun (2.2\% of farmers) landraces. For farmers the resistance of these common bean landraces was due to the hardness (Séssé landrace), thickness (Mitohikoun landrace) and black colour (Akpakoun wiwi landrace) of seed coat, and the seed bitter taste (Akpakoun vovo). Nevertheless, some landraces were noted as being very sensitive to storage insect attacks. The small-seeded white bean (Kpalagui) and the large flat white seed (Akpakoun wéwé) were the most susceptible landraces as reported by $40 \%$ of famers respectively. Akapakoun rouge was also considered to be very susceptible to storage insect pest attacks as reported by some farmers (20\%). For farmers, the susceptibility of these three common bean landraces is due to the fact that they have high moisture content in seeds.

\section{DISCUSSION}

In the study area, common bean production was confronted to several constraints. The availability of staking materials was the biggest problems for farmers, which was hampering common bean production in central Benin. Similar results have been reported by several authors in other African countries (Ruganzu et al., 2014; Gichangi et al., 2012; Musoni et al., 2014; Rujamizi et al., 2017). The reduction of tree plantations associated with the high cost of stick staking explains the unavailability of sticks for staking (Ntukamazina et al., 2014). In fact, in the study area the use of trees as stakes does not allow all farmers to grow common beans because few of them have trees in their fields. Similarly, this factor limits women's production of beans because the ownership of trees in the fields was the responsibility of the men, thus justifying the high number of surveyed men in this study. These staking needs in climbing beans production therefore, could lead to deforestation and subsequent environmental degradation (Gichangi et al., 2012; Musoni et al., 2014). However, some studies shown that farmers use alternative staking material such as stalks of maize and sorghum (Gichangi et al., 2012; Takusewanya et al., 2017). To improve common bean production in central Benin, the training of farmers on climbing beans intercropping production practises turns out to be necessary.

Interviews of farmers also revealed that lack of market was an important constraint in common bean production. Similar results were found by van De Luque et al. (2014) which show that lack of market access, price instability, and lack of credit were important common bean constraints. A common bean market study in central Benin must bean done because the knowledge of market dynamics are crucial to define a breeding strategy that meets the need of the farmers (Asfaw et al., 2013). Third constraint in the study area, the lack of seeds was also notified by some farmers in Uganda (Ronner et al., 2017), and Burundi (Birachi et al., 2011) and can be due to the poor yields in the previous season. There is an urgent need to train farmers associations of central Benin in common bean seed production, promote improved seeds and facilitate seed imports by government.

The study revealed subject to the synonymy, the existence of 12 common bean landraces across the study area. Although varietal diversity is important across the study area, it is low compared to that found in villages in Northern Malawi (15 landraces) (Martin and Adams, 1987), but higher than the number of landraces found is southern Ethiopia (6 landraces) (Asfaw et al., 2013). Education level was correlated to the number of common bean landraces held at household level. Similar results were obtained by Gichangi et al. (2012) which reported positive impact of education level on adoption and production of climbing beans. In fact, the level of education increases farmers' ability to obtain information and increase the probability to adopt good practises relevant to the production of climbing beans (Gichangi et al., 2012). To boost common bean production in central Benin, creating awareness and building capacity of farmers is necessary.

The mean number of common bean landraces held at the village level was higher than others pulses in Benin such as pigeonpea (Ayenan et al., 2017), and Kersting's groundnut (Assogba et al., 2015), but lower than that of cowpea (Gbaguidi et al., 2013). The loss of common bean diversity in the study area remains significant. A conservation programs (in situ and ex situ) of the existing diversity should therefore be put in place. The Doyissa and Enssèke villages had the highest varietal diversity and were therefore, best suited for in situ conservation programs for common bean genetic resources in central Benin. In this region, many common bean landraces have been abandoned by farmers and the documented abandonment reasons will guide breeders on the type of varieties to be created for the happiness of farmers.

The survey reveals that seed system was informal with majority of self-saved seed from the previous harvest or purchased from local markets. Similarly, common bean seed system in Ethiopia (Asfaw et al., 2013; Oshone, 2017), and Kenya (Opole et al., 2006) is essentially informal. In this informal seed system access to improved varieties is still a challenge to farmers leading to low production levels (Birachi et al., 2011). There is an urgent need for the development of formal seed system and by setting up production of breeder, pre-basic, and basic seed. Similarly to the result of this study, farmers in Ethiopia (Oshone, 2017) mainly used polyethylene bags for common bean post-harvest conservation probably because of their availability in the local markets and cheaper price.

Farmers mentioned that attack of stored common bean 
seeds by insects was the principal storage constraints. The bean weevil $A$. obtectus was the only insect pest of stored beans reported by farmers. This cosmopolitan insect pest has also been reported as the most important pest of stored beans in Asia (Thakur, 2012), America (Quentin et al., 1991; Silva and Costa, 2016 and Baldin et al., 2017), Africa (Rugumamu, 2014), Europa (Rugumamu, 2014) and Oceania (Daglish et al., 1993). In fact, larvae of $A$. obtectus enter the common bean seeds from the first instar stage and consume the reserves contained in the cotyledons which causes great losses (up to 30\%) (Baldin et al., 2017). Infestation of stored common beans by the bean weevil gives a characteristic pungent odour, making them unfit for consumption and reducing their market value (Paul et al., 2009). There is a need, therefore, to found environment friendly methods to protect stored common bean against bean weevil. Moreover, several studies shown the presence of another important common bean storage insect pest Zabrotes subfasciatus (Boheman) (Coleoptera: Bruchidae) in West Africa (Ayamdoo et al., 2013; Williams, 1980; Taylor, 1981). It is so essential to evaluate the diversity and abundance of insects associated with stored common beans in central Benin. Some farmers in the study area use chemicals insecticides to conserve their common bean seeds.

However, the use of these chemical pesticides in common bean preservation can cause damage to health by residual effects remaining in the grains. The use of plants for the protection of stored beans represents an alternative to the use of pesticides and is practiced by most farmers in central Benin. Except $C$. officinalis, all the others plants used by surveyed farmers for the protection of stored beans have proved insecticidal or insect repellent properties. Indeed, Rugumamu (2014), Niber et al. (1992), and Facknath (2006), proved the insecticidal effect of $A$. indica against $A$. obtectus in stored common beans. Similarly, the results of Rugumamu (2014) revealed direct contact toxicity of $O$. graticimum on $A$. obtectus. C. frutescens are commonly used for protection of common bean seeds in Northern Tanzania (Paul et al., 2009) and their insecticidal activity was proved on several storage insect pests such as Callosobruchus maculatus (F.) (Lale, 1992), and Sitophilus zeamais Motschulsky (Akinbuluma et al., 2015). The efficacy of $K$. senegalensis seed oil and powder as insecticide was demonstrated by Bamaiyi et al. (2007) as well as Nguemtchouin et al. (2010) shown the toxicity of $X$. aethiopica on S. zeamais in stored maize. It is therefore, important to evaluate the insecticidal and insect repellent properties of the 5 medicinal plants used by farmers of central Benin for the control of $A$. obtectus to broaden the range of available botanical insecticides for this pest.

A differential susceptibility of common bean landraces to storage insect pests was notified by surveyed farmers. In fact, Dobie et al. (1990) shown that the use of antilectin-like protein antibodies are a useful tool for distinguishing between resistant and susceptible bean varieties to $A$. obtectus and $Z$. subfasciatus. High moisture content of seeds was indicated by farmers as the susceptibility factor to storage insect attacks. This farmers' perception is corroborated by Delouche (1968) which notified that insect activity and damage also increases if seed moisture increase. As signalled by surveyed farmers the hardness (Stamopoulos and Huignard, 1980), and thickness (Stamopoulos and Huignard, 1980; Maldonado et al., 1996) of seed coat could be factors related to the resistance of common bean seeds to storage insects attack. Knowing that black seeds of some pulses such as Bambara groundnut (Baidoo et al., 2015) has shown resistance to $C$. maculatus, it is important to evaluate the preference of $A$. obtectus for a particular bean seed coat colour to confirm or refute farmers' perception of the black bean seeds' resistance to this pest.

\section{Conclusion}

This study has shown that several constraints hampered common bean production in central Benin with the lack of staking materials as the main constraint. The training of farmers on climbing beans intercropping production practises, and in common bean seeds production are important for the improvement of common bean production in the study area. An important common bean landraces diversity exist in central Benin with subject to the synonymy 12 common bean landraces recorded. However, morphological and molecular characterizations must be done to evaluate the existing common bean diversity. A high rate of threat of common bean landraces disappearance was recorded and the documented reasons of this disappearance will guide breeders on the type of varieties to be created for happiness of farmers. The Doyissa and Enssèke villages had the highest varietal diversity and are therefore best suited for in situ conservation programs for common bean genetic resources in central Benin. The seed system was essentially informal and thus, there is an urgent need for the development of formal seed system. The bean weevil $A$. obtectus was the only pest recognised by farmers. It is important to evaluate the diversity and abundance of insects associated with stored common beans in central Benin. Medicinal plants were used by most of farmers to control storage insect pest. The efficiency of the 5 medicinal plants recorded on the control of $A$. obtectus in this study should be tested to broaden the range of available botanical insecticides for this pest. The susceptibility of the four common bean landraces listed by farmers as resistant to storage insects must be evaluated.

\section{CONFLICT OF INTERESTS}

The authors have not declared any conflict of interests. 


\section{ACKNOWLEDGEMENTS}

Authors thank anonymous reviewers for their comments on previous versions of the manuscript. We express our sincere gratitude to all farmers, chiefs of village, and leaders of farmer groups for their contributions to the success of this study.

\section{REFERENCES}

Acosta-gallegos JA, Kelly JD, Gepts P (2007). Prebreeding in common bean and use of genetic diversity from wild germplasm. Crop Science 47:44-59.

Akinbuluma MD, Adepetun MT, Yeye EO (2015). Insecticidal effects of ethanol extracts of Capsicum frutescens and Dennettia tripetala against Sitophilus zeamais Motschulsky on stored maize. International Journal of Research in Agriculture and Forestry 2:1-7.

Asfaw A, Almekinders CJM, Struik PC, Blair MW (2013). Farmers' common bean variety and seed management in the face of drought and climate instability in southern Ethiopia. Scientific Research and Essays 8:1022-1037.

Assogba P, Ewedje E-EBK, Dansi A, Loko YL, Adjatin A, Dansi M, Sanni A (2015). Indigenous knowledge and agromorphological evaluation of the minor crop Kersting's groundnut (Macrotyloma geocarpum (Harms) Maréchal et Baudet) cultivars of Benin. Genetic Resources and Crop Evolution 63:513-529.

Ayamdoo AJ, Demuyakor B, Badii KB, Sowley ENK (2013). Storage systems for Bambara groundnut (Vigna subterranean) and their implications for bruchid pest management in Talensi-nabdam district, upper east region, Ghana. International Journal of Scientific and Technology Research 2:181-186.

Ayenan MAT, Danquah A, Ahoton LE, Ofori K (2017). Utilization and farmers' knowledge on pigeonpea diversity in Benin, West Africa. Journal of Ethnobiology and Ethnomedecine 13:1-13.

Azontonde AH (1991). Propriétés physiques et hydrauliques des sols au Bénin Soil water balance in the Sudano-Sahelian zone. International Association of Hydrological Sciences 199:249-259.

Baidoo P, Kwansa N, Annin C (2015). The role of seed coat and its pigmentation on the acceptance of Bambara groundnut (Vigna subterranea $\mathrm{L}$ Verdc) cultivars by the cowpea beetle, Callosobruchus maculatus $(\mathrm{F})$. Advances in Entomology 3:125-131.

Baldin ELL, Lara FM, Camargo RS, Pannuti LER (2017). Characterization of resistance to the bean weevil Acanthoscelides obtectus Say, 1831 (Coleoptera: Bruchidae) in common bean genotypes. Arthropod-Plant Interactions 11:861-870.

Bamaiyi LJ, Ndams IS, Toro WA, Odekina S (2007). Laboratory Evaluation of Mahogany (Khaya senegalensis (Desv) Seed Oil and Seed Powder for the Control of Callosobruchus maculatus (Fab) (Coleoptera: Bruchidae) on Stored Cowpea. Journal of Entomology 4:237-242.

Birachi EA, Ochieng J, Wozemba D, Ruraduma C, Niyuhire MC, Ochieng D (2011). Factors influencing smallholder farmers' bean production and supply to market in Burundi. African Crop Science Journal 19:335-342.

Brackmann A, Neuwald DA, Ribeiro ND, Freitas ST (2002). Conservation of three bean genotypes (Phaseolus vulgaris $L$ ) of the group carioca in cold storage and controlled atmosphere. Ciência Rural 32:911-915.

Daglish GJ, Hall EA, Zorzetto MJ, Lambkin TM, Erbacher JM (1993). Evaluation of protectants for control of Acanthoscelides obtectus (Say) (Coleoptera: Bruchidae) in navybeans (Phaseolus vulgaris (L)). Journal of Stored Product Research 29:215-219.

Delouche JC (1968). Precepts for Storage. Proc Short Course for Seeds men Mississippi State, University, Mississippi State, Mississippi pp. 85-119.

Dobie P, Dendy J, Sherman C, Padgham J, Wood A, Gatehouse AMR (1990). New sources of resistance to Acanthoscelides obtectus (Say) and Zabrotes subfasciatus Boheman (Coleoptera: Bruchidae) in mature seeds of five species of Phaseolus. Journal of Stored Product Research 26:177-186.
Facknath S (2006). Combination of neem and physical disturbance for the control of four insect pests of stored products. International Journal of Tropical Insect Science 26:16-27.

Food and Agricultural Organization (FAO) (2016). Food and Agricultural Organization of the United Nations. http://wwwfaostatorg, (accessed 19 February 2018)

Gbaguidi AA, Dansi A, Loko LY, Dansi M, Sanni A (2013). Diversity and agronomic performances of the cowpea (Vigna unguiculata Walp) landraces in Southern Benin. International Research Journal of Agricultural Science and Soil Science 4:936-949.

Gichangi A, Maobe SN, Karanja D, Getabu A, Macharia CN, Ogecha JO, Nyang'au MK, Basweti E, Kitonga L (2012). Assessment of production and marketing of climbing beans by smallholder farmers in Nyanza region, Kenya. World Journal of Agricultural Sciences 8:293302.

Jones MS, Alexander CE, Smith B (2018). Economic consequences of post-harvest insect damage in Rwandan common bean markets. Crop Protection 104:92-100.

Keneni G, Bekele E, Getu E, Imtiaz M, Damte T, Mulatu B, Dagne K (2011). Breeding Food Legumes for Resistance to Storage Insect Pests: Potential and Limitations. Sustainability 3:1399-1415.

Kombo GR, Dansi A, Loko LY, Orkwor GC, Vodouhé R, Assogba P, Magema JM (2012). Diversity of cassava (Manihot esculenta Crantz) cultivars and its management in the department of Bouenza in the Republic of Congo. Genetic Resources and Crop Evolution 59:17891803.

Lale NES (1992). Oviposition-deterrent and repellent effects of products from dry chilli pepper fruits, Capsicum species on Callosobruchus maculatus. Postharvest Biology and Technology 1:343-348.

Loko LEY, Toffa J, Adjatin A, Akpo AJ, Orobiyi A, Dansi A (2018). Folk taxonomy and traditional uses of common bean (Phaseolus vulgaris L.) landraces by the sociolinguistic groups in the central region of the Republic of Benin. Journal of Ethnobiology and Ethnomedicine 14:52.

Loko YL, Adjatin A, Dansi A, Vodouhé R, Sanni A (2015). Participatory evaluation of Guinea yam (Dioscorea cayenensis Lam- $D$ rotundata Poir complex) landraces from Benin and agro-morphological characterization of cultivars tolerant to drought, high soil moisture and chips storage insects. Genetic Resources and Crop Evolution 62:1181-1192.

Luz CEA, Araujo TA, Ribeiro AV, Bastos CS, Torres JB, Krieger YST (2017). Resistance of important bean genotypes to the Mexican bean beetle [Zabrotes subfasciatus (Bohemann)] during storage and its control with chemical synthetic and botanical insecticides. Australian Journal of Crop Science 11:1168-1175.

Maldonado SHG, Marín-Jarillo A, Castellanos JZ, Gonzálezde Mejía E, Acosta-Gallegosc JA (1996). Relationship between physical and chemical characteristics and susceptibility to Zabrotes subfasciatus (Boh) (Coleoptera: Bruchidae) and Acanthoscelides obtectus (Say) in common bean (Phaseolus vulgaris $\mathrm{L}$ ) varieties. Journal of Stored Product Research 32:53-58.

Martin GB, Adams MW (1987) Landraces of Phaseolus vulgaris (Fabaceae) in Northern Malawi I Regional variation. Economic Botany 41:190-203.

Martínez-Castillo J, Colunga-García MP, Zizumbo-Villarreal D (2008). Genetic erosion and in situ conservation of Lima bean (Phaseolus lunatus L) landraces in its Mesoamerican diversity center. Genetic Resources and Crop Evolution 55:1065-1077.

Missihoun AA, Milognon HW, Montcho D, Agbo RI, Sedah P, Agbangla C (2017). Diversité variétale et gestion paysanne des haricots cultivés du genre Phaseolus cultivés au Centre et au Sud Bénin (en Afrique de l'Ouest). Journal of Applied Biosciences 118:1181711828.

Mohammed MS, Shimelis HA, Laing MD (2016). Phenotypic characterization of diverse Bambara groundnut (Vigna subterranea [L] Verdc) germplasm collections through seed morphology. Genetic Resources and Crop Evolution 63:889-899.

Mojica L, de Mejía EG (2015). Characterization and Comparison of Protein and Peptide Profiles and their Biological Activities of Improved Common Bean Cultivars (Phaseolus vulgaris $\mathrm{L}$ ) from Mexico and Brazil. Plant Foods for Human Nutrition 70(2):105-112.

Musoni A, Kayumba J, Butare L, Mukamuhirwa F, Murwanashyaka E, Mukankubana D, Kelly JD, Ininda J, Gahakwa D (2014). Innovations 
to Overcome Staking Challenges to Growing Climbing Beans by Smallholders in Rwanda. In: Vanlauwe B, van Asten P, Blomme G (eds) Challenges and Opportunities for Agricultural Intensification of the Humid Highland Systems of Sub-Saharan Africa, Springer, Cham pp. 129-136.

Nguemtchouin MMG, Ngassoum MB, Ngamo LST, Gaudu X, Cretin M (2010). Insecticidal formulation based on Xylopia aethiopica essential oil and kaolinite clay for maize protection. Crop Protection 29:985991.

Niber BT, Helenius J, Varis AL (1992). Toxicity of plant extracts to three storage beetles (Coleoptera). Journal of Applied Entomology 113:202-208.

Ntukamazina N, Ruraduma C, Ntibashirwa S (2014). Relative performance of staking techniques on yield of climbing bean in highlands of Burundi. African Crop Science Journal 22:997-1001.

Opole RA, Mathenge PW, Auma EO, Van Rneenen HA, Wambugu PW (2006). On-farm seed storage of common bean in western Kenya. African Crop Science Conference Proceedings 7:1173-1178.

Orobiyi A, Loko YL, Sanoussi F, Adjatin A, Gbaguidi A, Dansi A, Sanni A (2017). Horticultural practices and varietal diversity of chili pepper (Capsicum annuum L) in Central and Northern Benin. Genetic Resources and Crop Evolution 64:419-436.

Oshone K (2017). Common Bean (Phaseolus vulgaris L) Seed Systems in West Hararghe, Eastern Ethiopia. Journal of Agricultural Science and Food Technology 3:7-14.

Paul UV, Lossini JS, Edwards PJ, Hilbeck A (2009). Effectiveness of products from four locally grown plants for the management of Acanthoscelides obtectus (Say) and Zabrotes subfasciatus (Boheman) (both Coleoptera: Bruchidae) in stored beans under laboratory and farm conditions in Northern Tanzania. Journal of Stored Product Research 45:97-107.

Pujolà M, Farreras A, Casañas F (2007). Protein and starch content of raw, soaked and cooked beans (Phaseolus vulgaris L). Food Chemistry 102:1034-1041.

Quentin E, Spencer JL, Miller JR (1991). Bean tumbling as a control measure for the common bean weevil, Acanthoscelides obtectus. Entomologia Experimentalis et Applicata 60:105-109.

Ronner E, Descheemaeker K, Almekinders CJM, Ebanyat P, Giller KE (2017). Farmers' use and adaptation of improved climbing bean production practices in the highlands of Uganda. Agriculture, Ecosystems and Environment 261:186-200.

Ruganzu V, Mutware J S, Uwumukiza B, Nabahungu NL, Nkurunziza I, Cyamweshi AR (2014). Farmers' Knowledge and Perception of Climbing Beans-Based Cropping Systems in Rwanda. In: Vanlauwe $\mathrm{B}$, van Asten P, Blomme G (eds) Challenges and Opportunities for Agricultural Intensification of the Humid Highland Systems of SubSaharan Africa, Springer, Cham pp. 39-49.

Rugumamu CP (2014). Potency of Traditional Insecticide Materials against Stored Bean Weevil, Acanthoscelides obtectus (Coleoptera: Bruchidae) in Tanzania. Huria: Journal of the Open University of Tanzania 16:126-139.

Rujamizi MJ, Kujirabwinja R, Matabaro A (2017). Les causes de la régression de la culture du haricot volubile en groupement de Miti. International Journal of Innovative Research in Science, Engineering and Technology 33:277-281.

Silva TT, Costa FM (2016). Survey of Insects that Attack Stored Bean Grains Vigna unguiculata $(\mathrm{L})$ and Phaseolus vulgaris $L$ in Porto Velho, Rondônia, Brazil. Publicação do Projeto Entomologistas do Brasil 9:124-128.
Stamopoulos D, Huignard J (1980). L'influence des diverses parties de la graine de haricot (Phaseolus vulgaris) sur le développement des larves d'Acanthoscelides obtectus (Coléoptère Bruchidae). Entomologia Experimentalis et Applicata 28:38-46.

Takusewanya R, Namayanja A, Bwogi GV, Mwine J, Odong TL (2017). Assessment of staking in a climbing bean production system as practiced by smallholder farmers in Uganda. Journal of Crop Science and Agronomy 2:018-027.

Taylor TA (1981). Distribution, ecology and importance of bruchids attacking grain legumes and pulses in Africa. In: Labeyrie V (eds) The Ecology of Bruchids Attacking Legumes (Pulses) Series Entomologica, Springer, Dordrecht 19:199-203.

Thakur DR (2012). Taxonomy, Distribution and Pest Status of Indian Biotypes of Acanthoscelides obtectus (Coleoptera: Chrysomelidae: Bruchinae) - A New Record. Pakistan Journal of Zoology 44:189-195.

van De Luque JR, José J, Creamer B (2014). Principal constraints and trends for common bean production and commercialization; establishing priorities for future research. Agronomia colombiana 32:423-431.

Williams JO (1980). Note on Bruchidae associated with stored products in Nigeria. Tropical Grain Legume Bulletin 21:5-10. 